Prof. dr. Osman Ramić

\title{
SPECIFIČNOSTI RADA S DJECOM PRVOG RAZREDA OSNOVNE ŠKOLE
}

\section{Ključne riječi:}

Integracija, tolerancija, kooperativnost, socioemocionalna zrelost, dominacija, socijalizacija, saradnja, egocentrizam, psihofizički razvoj, emocionalne, socijalne i intelektualne i druge podsticajne reakcije, temperament, lateralizacija, pažnja i pamćenje šestogodišnjaka, djeca $\mathrm{s}$ teškoćama u razvoju, djeca $\mathrm{s}$ posebnim potrebama, inkluzija.

\section{Sažetak}

Početak devetogodišnjeg osnovnog školovanja ima posebne specifičnosti $i$ značenje s obzirom na socijalnu i emocionalnu zrelost šestogodišnjaka $i$ njihovu pripremljenost za izvršavanje zahtjeva $i$ zadataka koje nameće prvi razred osnovne škole. Početak školovanja predstavlja prekretnicu u životu djeteta i nije beznačajno kako će dijete doživjeti ovaj početak. Ova prekretnica praćena je i primjenom reforme obrazovanja koja je najočitije primijenjena na prvačićima. Pripremljenost djece, uključujući $i$ djecu bez roditeljskog staranja, za kolektivni rad, za složenost obaveza koje proizilaze iz složenosti programskih sadržaja nastavnih predmeta mora postati predmetom bavljenja psihologa, pedagoga, socijalnih radnika, nastavnika $i$ drugih koji se na bilo koji način bave pitanjima odgoja i obrazovanja djece mlađeg školskog uzrasta. Istraživanje ovih problema doprinijet će dobivanju odgovora na relevantna pitanja koja se odnose na pripremljenost šestogodišnjaka za polazak u školu što će, nastavnicima kao neposrednim realizatorima programskih sadržaja $i$ odgoja $i$ obrazovanja učenika, pomoći da u cijelosti $i$ uspješno ostvaruju svoju funkciju. Ovo je posebno značajno za uspješan rad nastavnika s djecom koja imaju teškoće u razvoju, s djecom $s$ posebnim potrebama kao $i$ s djecom bez roditeljskog starenja. $U$ današnje vrijeme ova pitanja su posebno aktuelna, u razvijenim zemljama svijeta $i$ znatno ranije. $S$ tim $u$ vezi, inkluzivni odgoj $i$ 
obrazovanje ima značajnu ulogu $i$ u našem sistemu odgoja $i$ obrazovanja sve više zaživljava. To je jedan od značajnih razloga da se $u$ sistemu osposobljavanja $i$ stalnog stručnog usavršavanja nastavnika adekvatna pažnja pokloni usavršavanju iz područja specijalne pedagogije i psihologije djece s teškoćama u razvoju.

Krenimo sa nekoliko pitanja:

Da li svi prvaci pokazuju interes za igru?

Jesu li sva djeca koja polaze u prvi razred pripremljena za polazak u školu?

Koliko prosječno djeca ovog uzrasta pješače od kuće do škole i nazad do kuće? snazi?

Koliko je teška dječija torba i odgovara li ta težina njihovoj

Jesu li pjevanje i crtanje sastavni dio svakodnevnih aktivnosti djece u prvom razredu osnovne škole?

Zna li se sa sigurnošću da su sva djeca došla u školu nahranjena i da li su sva imala šta jesti?

Pitanja imaju za cilj da potaknu na razmišljanje i buđenje interesa za sagledavanje svih relevantnih faktora koji imaju udjela $u$ stvaranju povoljne socioemocionalne klime $u$ odjeljenju kao pretpostavke uspješnog rada nastavnika i učenika.

Za uspješan rad sa šestogodišnjom djecom neophodno je da nastavnici poznaju osnovne karakteristike djece ovoga uzrasta.

Neka psihofizička obilježja šestogodišnjaka

Za uspješan rad sa šestogodišnjom djecom u I. razredu neophodno je da nastavnik prikupi što veći broj konkretnih informacija koje će olakšati rad i omogućiti nastavniku da u radu primijeni aktivno učenje. Prema psihološkim istraživanjima smatra se:

- da šestogodišnja djeca mogu biti relativno samostalna $u$ izvršavanju jednostavnih poslova kao: oblačenje, obuvanje, održavanje higijenskih navika, znaju prepoznati opasnosti koje im svakodnevno prijete dok se kreću u okolini i sl;

- da su tjelesne proporcije iste kao i kod odrasla čovjeka; 
- šestogodišnjaci se mogu uspješno fokusirati na zadatke i održati pažnju tokom dužeg vremena, ali su, tokom rješavanja zadataka, potrebne promjene, dinamičan rad i kraće pauze;

- da su šestogodišnja djeca pod utjecajem sazrijevanja i sredine savladala osnove gramatike, fonetike i sintakse, da raspolažu s odgovarajućim fondom riječi koje im omogućavaju nesmetanu komunikaciju s nastavnikom, vršnjacima i ostalim u sredini u kojoj žive. Ipak, treba istaći da razvoj govora još nije potpuno završen i da postoji potreba daljeg uvježbavanja i usavršavanja. U odgojno obrazovnom radu kompozicija i dužina rečenice, njeno ispravno artikuliranje, oslobođenost od nepoznatih riječi od strane onih koji upućuju djeci informacije u značajnoj mjeri će pomoći daljem razvoju govora i stvaranju preduvjeta za aktivno učenje. Loš uzor može usporiti i otežati razvoj govora djece pa otuda još veća potreba da se rečenice i uopće govor nastavnika u što većoj mjeri odnose na konkretne situacije, konkretne predmete i osobe;

- da je psihofizički razvoj šestogodišnjaka pod utjecajem procesa lateralizacije, tj procesa uspostavljanja dominacije jedne strane tijela koji se završava između 6. i 7. godine života. U 80 - 95 \% slučajeva to je desna strana tijela, a kod ostalih se javlja ljevorukost, ambidekstrija i sl. Poznato je da je lijeva hemisfera sjedište funkcija govora, pisanja, računanja, apstraktnog mišljenja, logičke analize pa otuda djeca sa šest godina još ne mogu da formiraju pojmove u njihovom pravom značenju i zato se razvoj govora, čitanje, pisanje, računanje, usklađuju s ovim psihološkim karakteristikama djece ovog uzrasta;

- da se mogućnosti za učenje, posebno aktivno učenje zasniva na sposobnosti pamćenja, a pamćenje kod šestogodišnjaka je pretežno kratkotrajno. To zahtijeva da se pojedini programski sadržaji saopćavaju, ponavljaju i uvježbavaju više puta, ali ne u istom obliku, već u različitim varijantama. Tako o školskom dvorištu učenici treba da razgovaraju kao o mjestu za igru i razonodu, kao o prostoru za okupljanje, kao o ekološkom prostoru kojeg uređuju i sl. Na sličan način razgovarat će o školskom cvijetnjaku, o učionici-igraonici itd.

- uspješan rad zavisi od sposobnosti održavanja pažnje kod djece. Pažnja kod šestogodišnjaka je, uglavnom, spontana, nenamjerna, frustuirajuća, brzo se mijenja, teško je održati i lahko joj je promijeniti namjeru. Na ovom uzrastu djeca se mogu koncentrirati na jedan zadatak. Što su sadržaji raznovrsniji to će i pažnja biti bolja i 
stabilnija pa je preporučljivo da se u toku nastavnog sata kombiniraju aktivnosti aktivnog učenja s muzikom i pjesmom, crtanjem, vježbama uz korištenje više kraćih pauza;

- percepcija, pamćenje, pažnja, mašta, motivacija kod šestogodišnjaka su u fazi formiranja pa s tim u vezi su i vrste igara koje se koriste tokom rada, a najpoželjnije su igranje uloga;

- šestogodišnjaci imaju poteškoća u dinamici uspostavljanja koordinacije i razvoja preciznih pokreta jer sitni mišići ruke još nisu potpuno razvijeni, okoštavanje prstiju još nije završeno, imaju slabu statičku izdržljivost koja je u vezi s mirnim položajem tijela pri crtanju, pisanju i drugim sjedećim aktivnostima. To neminovno zahtijeva od nastavnika da redovito navikavaju djecu na pravilno sjedenje i pravilno držanje tijela, pravilno disanje, pravilno držanje i upotrebu pribora i materijala i tako spriječe pojavu deformiteta kičmenog stuba. Dugotrajno statičko opterećenje djece je nepovoljno jer smanjuje intelektualne i motorne aktivnosti;

- socijalne interakcije, prihvatanje pravila ponašanja, stavova drugih, komunikacija $\mathrm{s}$ nastavnikom i vršnjacima ukazuju na određene karakteristike zrelosti djeteta za razne aktivnosti i za aktivno učenje. Prihvaćenost od vršnjaka, dobra saradnja, kooperativnost, komunikativnost, osjetljivost za potrebe druge djece, uspješno savladavanje različitih aktivnosti, sigurni su pokazatelji da se dijete pravilno razvija. U protivnom, kod djece se javlja nezadovoljstvo, inferiornost, gubitak volje za aktivnosti, odbojnost, povlačenje u sebe, nekooperativnost, slab rad i angažiranje što predstavlja sigurna upozorenja da djetetu treba pomoć nastavnika i kolektiva;

- emocionalne reakcije i ponašanja su povezane sa socijalnim interakcijama. Za djecu ovog uzrasta karakteristično je da su emocije veoma promjenljive, da su veoma osjetljivi na nepravdu, da se lahko povrijede $\mathrm{i}$ da, zavisno od temperamenta, reagiraju burno, naglo, plačem i gnjevom.

Polaskom u školu kod djece dolazi do većeg broja promjena.

- Dosadašnje spontane i promjenljive aktivnosti zamjenjuju se sistematskim i dugotrajnim školskim aktivnostima što djeci teško pada dok se ne stvore navike.

- Do sada slobodno kretanje zamijenjeno je ograničenim motornim aktivnostima. 
- Duži boravak u učionici, sjedenje u klupi izaziva veliko statičko opterećenje koje djeca jako teško podnose. Smatra se da ove promjene mogu proizvesti « školski stres « « školski šok «, « adaptacionu bolest «. Sva djeca nisu spremna na ovakva opterećenja i potrebno je voditi računa o postepenom prelasku u zahtjevnu školsku radnu atmosferu.

$\mathrm{S}$ obzirom na temperament, djecu možemo posmatrati $\mathrm{s}$ aspekta prilagodljivosti, stabilnosti ili rasijanosti pažnje, upornosti, redovitosti, povučenosti, aktivnosti, jačini reakcija, promjenjivosti raspoloženja i dr. S tim u vezi, djecu ovog uzrasta možemo svrstati u nekoliko grupa kao:

- djeca fleksibilna i jednostavna za saradnju. Lahko se prilagođavaju promjenama, brzo prihvataju nove izazove, prijatni su i raspoloženi, biološke funkcije i vlastite reakcije su im uspješne;

- djeca koja teže prihvataju promjene i iznenađenja, imaju prisustvo straha, bježe od novih iskustava, teško se prilagođavaju novim situacijama, samo kad su sigurni slobodno i pozitivno reagiraju;

- stidljiva djeca koja su nježna, naglašenije introvertna, ali znaju biti kreativna. Stidljivost može biti naslijeđena, ali i posljedica socioemocionalne klime u porodici.

- živahna, ponekad hiperaktivna i problematična djeca koja manifestuju bježanje od novih osoba, teško usvajaju promjene, često mijenjaju raspoloženja i glasno ih izražavaju, imaju snažne reakcije i sl.

U odgojno - obrazovnom radu veoma je važno da nastavnici zapaze i identifikuju obilježja koja djecu svrstavaju u neku od grupa, da iznalaze načine preusmjeravanja nepoželjnih osobina, da razgovaraju o promjenama. $\mathrm{Na}$ dječije reakcije treba reagirati fleksibilno i prilagodljivo, smireno i s puno razumijevanja prihvatati njihove oblike ponašanja. Omogućiti djeci slobodu izbora aktivnosti uz puno uvažavanje njihovih interesa, sposobnosti, želja i mogućnosti i na taj način osigurati im pravilan tretman.

\section{Praćenje i podsticanje aktivnog učenja}

Ocjenjivanje je opisno i primjereno je djeci mlađeg školskog uzrasta. 
U svakom nastavnom predmetu i na svakom nastavnom satu definirani su ciljevi koje treba ostvariti i indikatori uspješnosti.

$\mathrm{Za}$ svakog učenika treba utvrditi mjesto, poziciju na skali uspješnosti i to kvalitativno.

U ocjenjivanju je potreban sistematski rad na praćenju napredovanja.

Za svakog učenika u nastavnom predmetu može se ustanoviti inicijalno stanje na osnovu kojeg ćemo moći ustanoviti promjene i napredovanje.

Zavisno od namjene onoga šta se procjenjuje, treba pripremiti skale za procjenu koje mogu biti višedijelne i što osjetljivije kako bismo svakog učenika što realnije ocijenili. U cilju ostvarivanja aktivnog učenja nastavnici treba da koriste podsticajne naputke koji mogu biti sadržani u osmišljenim skalama npr.

Neke polazne pretpostavke:

- dolazak u školu: veoma otežan, s teškoćama, jednostavan, radostan,

- korištenje torbe i pribora: bez poteškoća, s naporom, nije u stanju sam,

- uključivanje u rad grupe: aktivan, usporen, indolentan,

- održavanje higijenskih navika: bez poteškoća, s manjim poteškoćama, ima ozbiljnih poteškoća i sl.

Intelektualne reakcije:

- pažnja: visoka, dobra, kratkotrajna, labilna, veoma slaba,

- pamćenje: veoma dobro, dobro, kratkotrajno, slabo,

- učešće u radu na nastavnom satu: superioran, aktivan, uključuje se, pasivan,

- usvojenost sadržaja: potpuno, solidno, djelimično, ne usvaja sadržaje,

- uspješnost učenika: u svim oblastima, samo u nekim predmetima, u odgojnim područjima,

- napredak u odnosu na početak: izvanredan, solidan, djelomičan, bez napretka, primjetna stagnacija. 
Socijalne interakcije:

- komunikativnost: izvanredna, vrlo dobra, solidna, slaba,

- odnos prema vršnjacima : saradnički, egoističan, altruističan, empatičan, agresivan, drzak,

- poteškoće: govorne, psihomotorne, socijalni kontakti, emocionalne,

- odnos prema nastavniku: veoma povoljan, dobar, bezvoljan, ne prihvata nastavnika i sl.

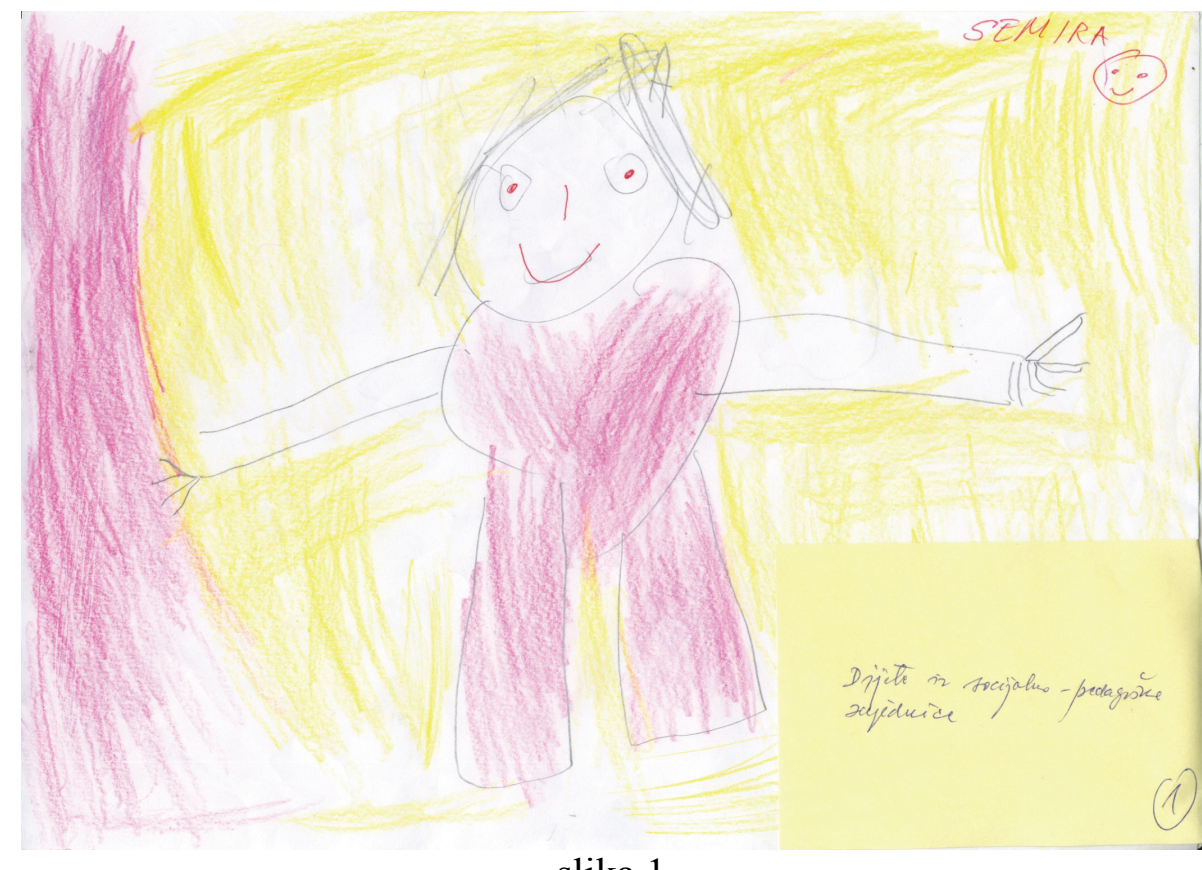

slika 1

Dijete iz socijalno - pedagoške zajednice

Emocionalne reakcije:

- ocjene iz znanja prihvata: sa zadovoljstvom, smireno, pokorno, uz nepoželjne reakcije;

- razne aktivnosti: dominira, nametljiv, mirno reagira, svadljiv,

- ponašanje u dvorištu: razigrano i raspoloženo, uključuje se, stidljiv, buntovno, ponekad plače, povlači se. 
Ponašanje u grupi:

- prijateljski, druželjubiv, saosjećajan, grub, netolerantan, agresivan, pohlepan, prkosan.

Reakcije za vrijeme radnih aktivnosti:

- radoznao, zainteresiran, pokazuje znake kreativnosti, ima organizatorske sposobnosti, pasivan, nezainteresiran, sklon ometanju i omalovažavanju, sujetan.

Istaknuto je da su ovo samo neki od načina reagiranja i načina podsticanja, a odgajateljima se ostavlja puna sloboda da proširuju listu obilježja s vlastitim zapažanjima i identifikacijama. Svakodnevno praćenje napredovanja učenika i obavještavanje o rezultatima učenika i roditelja, jedan je od sigurnih načina podsticanja učenika na učenje i aktivnost. 


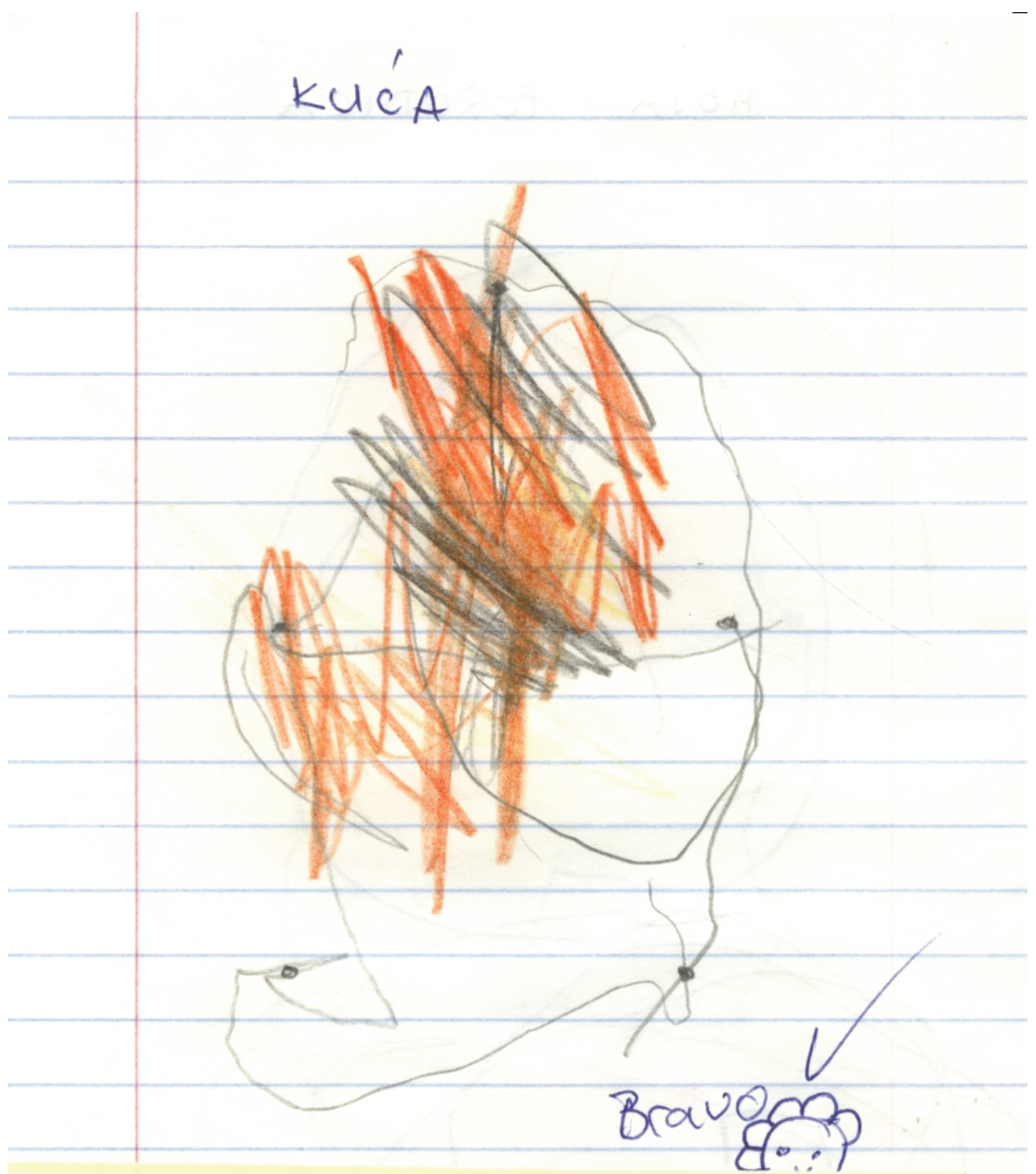

Slika 2

Način podsticanja učenika s težim psihičkim smetnjama u razvoju

Djeca s teškoćama u razvoju i djeca s posebnim potrebama

Sva djeca s lakšim smetnjama psihičke, emocionalne, socijalne ili fizičke prirode treba da budu integrirana u redovna odjeljenja i da se odgajaju i obrazuju u redovnim odjeljenjima. Teži slučajevi i dalje će biti upućivani u specijalne zavode. 
Pretpostaviti je da će biti dosta odjeljenja u kojima neće biti ni jedno dijete $s$ izraženim nepovoljnim posebnim potrebama, ali bit će $i$ onih gdje će se poneko takvo dijete pojaviti. Pored rada u redovnoj nastavi s ostalom djecom, za ove učenike potrebo je pripremati individualizirane programe i uz pojačan pedagoški rad i individualne kontakte pomoći im da lakše savladaju potrebne sadržaje.

U svakodnevnoj stvarnosti, to su najčešće djeca iz nepotpunih porodica, djeca iz socijalnopedagoških zajednica ili ustanova za prihvat i brigu o njima, djeca koja su zlostavljana, djeca sa fizičkim ili psihičkim traumama. Zavisno od vrste i stepena oštećenja, od nivoa izraženosti određene vrste poremećaja, za ovu djecu potrebno je:

- svakodnevno stvarati povoljne pedagoške situacije,

- više ih hrabriti, podržavati, češće pohvaljivati,

- nikad svjesno otežavati, omalovažavati, a pogotovo bilo koji oblik ponižavanja ili vrijeđanja djece.

U sistemu mjera pružanja pomoći djeci s posebnim potrebama poseban problem predstavlja pedagoška i opća kultura roditelja, a posebno majke. Rad na njihovom pedagoškom odgoju i obrazovanju kako bi uspješnije odgajale svoju djecu, posebna je briga škole ako želi ostvariti ciljeve, zadatke i odgojne vrijednosti savremene škole. Intenzivna saradnja škole i porodice, zajednička briga u rješavanju i zadovoljavanju posebnih potreba djece značajno će doprinijeti uspješnijem i potpunijem rješavanju uočenih poteškoća i problema $u$ cjelovitijem odgoju učenika. Dobra saradnja škole i porodice imat će za rezultat bolji uspjeh učenika koji je pod utjecajem povoljnog sklopa faktora unutar ličnosti i izvan nje. 


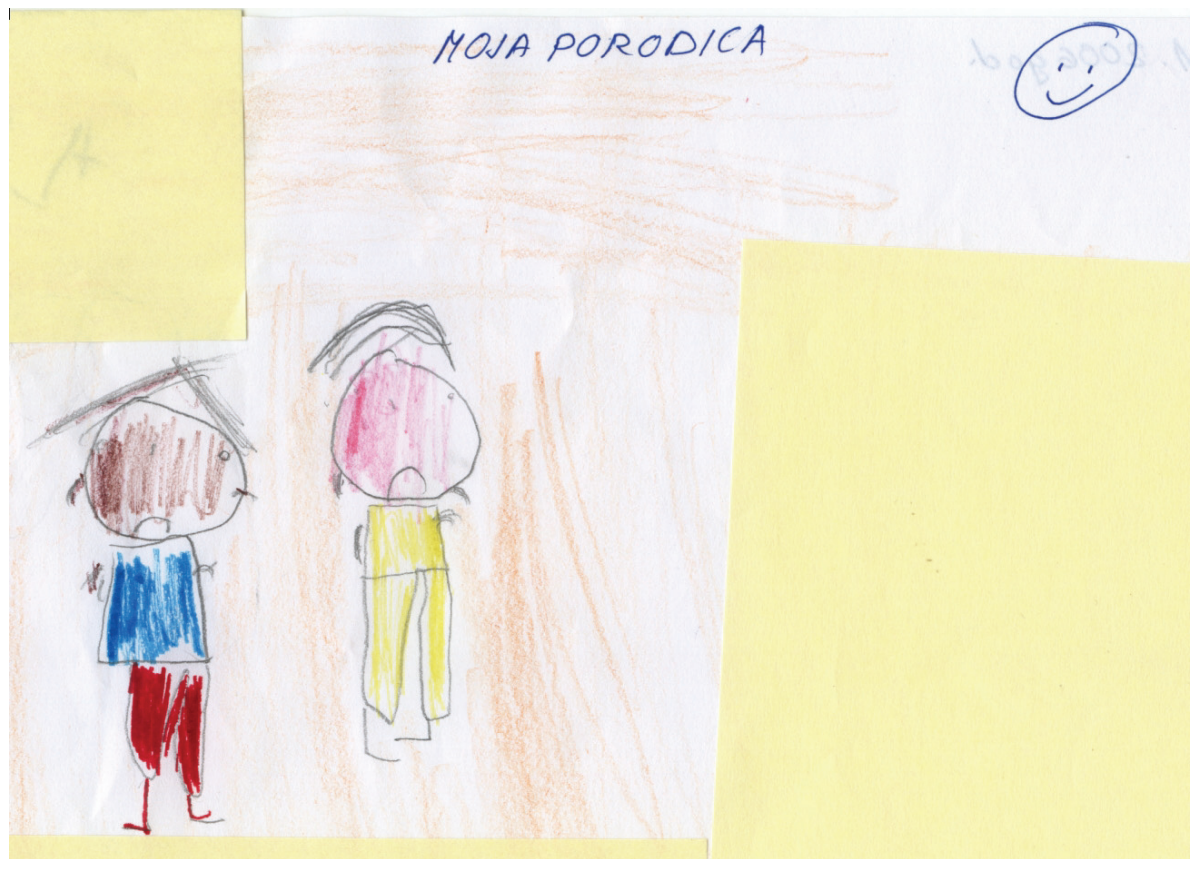

Slika 3

Dijete iz socijalno - pedagoške zajednice

Pored inteligencije koja se često smatra najvažnijim preduvjetom za uspješno učenje, nužno je uvažavati sposobnosti za učenje, posebno kreativne sposobnosti, snažne sredinske faktore, odgojne utjecaje porodice i škole te aktivan odnos pojedinca prema zadacima koje treba izvršavati, uvažavajući njegove posebne potrebe. Činjenica je da učenici s posebnim potrebama i s teškoćama u razvoju imaju potrebu da budu uspješni u određenim područjima pa i u učenju i zato je potrebno:

- da su upućeni šta treba da znaju,

- moraju znati šta se od njih traži i očekuje,

- učiti ih da se prilagođavaju uvjetima rada i strukturi vlastite ličnosti.

Kroz uvažavanje posebnih potreba učenika nastavnici bi morali njegovati što originalniji stil učenja svakog učenika ponaosob, jer se time razvija kognitivna sfera, stil mišljenja i prilaženja u rješavanju problema oslobođen od stereotipija i šablona, stabilizira se emocionalna uravnoteženost i socijalna prihvatljivost učenika. 
Uloga nastavnika u identifikaciji učenika kojima je potreban poseban tretman je ogromna i nezamjenjiva. Radeći svakodnevno sa djecom, nastavnici kroz redovnu i ostale vidove nastave vrlo uspješno otkrivaju djecu s posebnim potrebama.

Informacija o napredovanju, o postignutim rezultatima $\mathrm{i}$ potvrda da je uspješan u određenoj aktivnosti izaziva interes za edukaciju i za odabranu aktivnost. S tim u vezi, veoma je bitno i važno:

- identifikovati repertoar sposobnosti i mogućnosti osobe,

- uskladiti ciljeve i zadatke prema sposobnostima i mogućnostima,

- izvršiti adekvatan izbor metoda edukacije,

- registrirati pravovremeno napredovanja i redovito voditi neophodnu dokumentaciju,

- izvršiti izbor i korištenje najpodesnijih strategija za uspješno educiranje,

- osigurati pravilan odnos prema svima uz uvažavanje sposobnosti, interesa, želja i mogućnosti,

- uskladiti zahtjeve edukacije prema posebnim potrebama svakog pojedinca,

- omogućiti individualni i samostalni rad.

- U procesu edukacije nisu rijetki slučajevi da se naprave i određene pogreške prema učenicima, a one proizilaze iz:

- skromnog i ograničenog poznavanja strukture ličnosti učenika,

- slabog poznavanja osnovnih obilježja sredine i mentaliteta stanovništva,

- procjenjivanje sopstvene ličnosti u ulozi edukatora i nametanje volje po principu autoriteta,

- robovanja šablonima i stereotipijama bez uvažavanja specifičnosti osoba koje se educiraju,

- slabih perceptivnih sposobnosti i lošeg profesionalnog odnosa,

- skromna znanja pa otuda pojava nesigurnosti i konfuzije,

- korištenja i primjene zastarjelih metoda i nastavnih sredstava. 
S aspekta odgojno - obrazovnog rada vrlo važno je blagovremeno identificiranje djece koja posjeduju nadarenost, darovitost ili talentiranost kako bi se organizacija nastavnog i vannastavnog rada uskladila s potrebama učenika. Iako je riječ o šestogodišnjacima $i$ prvacima, nije na odmet da se o ovim karakteristikama govori već na ovom nivou.

Općenito, dokazano je da darovitost i kreativnost obuhvataju znatno širi sklop osobina ličnosti, nego što su to samo intelektualna svojstva. To znači da je darovitost i kreativnost određena cjelokupnom strukturom ličnosti u kojoj kognitivne sposobnosti predstavljaju samo jedan aspekt ličnosti.

Furlan ističe da se najčešće spominju dva usporedna izraza za intelektualno darovitu i kreativnu djecu. Prema Furlanu, «nadaren» ima nešto pasivnije obilježje od pojma «daroviti». Pored toga, prema Furlanu, kod nas postoji izraz « talentirano dijete « koji se vezuje za neko specifično područje kao: talenat za muziku, za jezik, matematiku, likovno itd. Prema R. Kvaščevu, darovitost i kreativnost pojedinca moguće je ispitati:

- izučavanjem stvaralačkih proizvoda i kreativnih procesa darovitih i kreativnih osoba;

- proučavanjem ličnosti učenika, njihovih sposobnosti i osobina ličnosti koje se manifestuju u svakodnevnom životu i radu. Sve važnije sposobnosti i osobine ličnosti darovitih i kreativnih pojedinaca, Kvaščev klasificira u sljedeće grupe:

- kognitivne sposobnosti,

- crte temperamenta i karaktera,

- motivacione osobine,

- kognitivni stil kreativnih osoba,

- kreativni stavovi,

- preferencije i sistemi vrijednosti kreativnih pojedinaca.

Prema Katelu bitni uvjeti kreativnog rada su:

- povoljna socijalno - kulturna klima,

- visoka individualna obdarenost praćena sposobnostima, osobinama temperamenta, karaktera i motivacije,

- zadovoljavajući ekonomski uvjeti, 
- istraživačke navike i sposobnosti mišljenja, koncentracije i motivacije,

- ličnost u cjelini i njen nivo aspiracije i motivacije.

Smatra se da su kreativni pojedinci bar prosječno inteligentni, jer kreativnost je uvjetovana $i$ drugim faktorima, a ne samo inteligencijom.

Istraživanja odnosa kreativnosti i inteligencije potvrđuju:

- da su kreativni pojedinci bar prosječno inteligentni,

- da inteligentniji pojedinci ne moraju biti i kreativni,

- da je kreativnost, osim inteligencije, uvjetovana i drugim faktorima,

- da sadržaj kreativnosti čine i psihološki procesi sadržani u pojmovima: intuicije, otkrića, radoznalosti, imaginacije, eksperimentisanja i istraživanja.

U odgojno-obrazovnom radu primijećeno je da učenici koji su pokazivali visoke rezultate na testovima inteligencije, nisu postizali visoke rezultate u drugim intelektualnim funkcijama - kao što je, npr. kreativnost.

Isto tako pokazalo se da učenici koji su pokazivali visoke rezultate $\mathrm{u}$ oblasti kreativnosti nisu postizali visoke rezultate na testovima inteligencije.

Primjeri za visoko inteligentne $\mathrm{i}$ visoko kreativne tipove ličnosti:

- visoko inteligentni: ambiciozni, dolaze da preuzmu zadatak prije vremena, stalno uče, hoće da pokažu drugima svoju marljivost, očekuju nagrađivanje;

- za visoko kreativne osobe karakteristično je da žele pod svaku cijenu ostvariti cilj, ne provjeravaju ispravnost postupaka, rado ulaze u rizike, često griješe zbog prenapregnutog nastojanja pa znaju sve upropastiti.

Dakle, inteligencija je neophodan, ali ne i jedini i dovoljan uvjet stvaralaštva. Drugo je što školski sistem više favorizira intelektualne sposobnosti pa su tokom cijelog školovanja najviše provjeravane.

Ispitivanja su potvrdila da postoje razlike između kreativnih sposobnosti i inteligencije u pogledu utjecaja na školski uspjeh.

$\mathrm{Na}$ osnovu rezultata na testovima inteligencije i na testovima kreativnosti učenici su podijeljeni na grupe: 
a) visoko inteligentni,

b) visoko kreativni,

c) nisko inteligentni,

d) nisko kreativni.

Utvrđeno je:

- da su visoko inteligentni učenici postizali bolje rezultate na svim testovima znanja u odnosu na nisko inteligentne;

- visoko kreativna grupa nije se značajno razlikovala na testovima znanja u odnosu na nisko kreativnu grupu.

Zaključak: rezultati zavise od kvaliteta nastave i osposobljenosti nastavnika za odgojno-obrazovni rad, karakteristika ličnosti nastavnika i učenika i specifičnih interesa kreativnih i manje kreativnih učenika.

Vidovi odgojno-obrazovnog rada s nadarenim i kreativnim učenicima

Do danas su provjereni i afirmirani oblici nastavnog rada za podsticanje darovitosti i kreativnosti kao:

- homogeno grupisanje,

- školska akceleracija ili ubrzano napredovanje,

- obogaćeni nastavni programi.

Homogeno grupisanje - podrazumijeva omogućavanje posebnog tretmana sa odgovarajućim programima za darovite i kreativne pojedince $\mathrm{u}$ skladu $\mathrm{s}$ njihovim sposobnostima i mogućnostima (zadovoljavanje individualnih potreba pojedinaca).

Ovaj način rada ima i svoje nedostatke kao:

- izdvajanje iz populacije može biti i štetno jer, osim kognitivnog razvoja u kojem su daroviti i kreativni napredni, mogu zaostajati u emocionalnom, socijalnom, fizičkom razvoju;

- pojava inhibicije u razvoju i radu zbog svijesti o tome šta se od njih očekuje;

- uskraćuju se znanja i aktivnosti darovitih prosječnim učenicima pa su i oni inhibirani u tom smislu;

- jača konkurencija i takmičarski duh može stvoriti loše socijalno - emocionalne odnose u odjeljenju kao i uskraćivanje razvoja socijalnih osobina kod darovitih i kreativnih;

- upitno je da li se darovitost ustanovila pravim postupcima; 
- uskraćivanje ostvarivanja integracije učeničkih interesa i aktivnosti.

Da bi se izbjegli ovi nedostaci - daroviti i kreativni učenici ostaju u redovnim odjeljenjima, a samo u određeno vrijeme ili određene dane okupljaju se u homogene grupe kad se rade posebno pripremljeni programski sadržaji koji njima odgovaraju.

Ubrzano napredovanje ili školska akceleracija-podrazumijeva brže napredovanje i brže završavanje određene škole što može imati višestruku korist. Opasnost je u tome što se smanjuju mogućnosti darovitim učenicima za bavljenje i drugim vannastavnim aktivnostima. Učenici su pod presijom hoće li uspjeti završiti razred, odnosno školu na planirani način;

U trci za ostvarivanjem akceleracije daroviti i kreativni mogu više izgubiti nego dobiti.

\section{Obogaćeni programi za darovite i kreativne}

U SAD se koristi ovaj vid podsticanja napredovanja i razvoja darovitih i kreativnih učenika. Nastavnici mu daju odgovarajući značaj jer smatraju da se tako podstiče motivacija učenika za učenje $\mathrm{i}$ omogućuje se optimalan razvoj sposobnosti, vještina i navika ovih učenika.

Obogaćenim programima moguće je provoditi uspješnu individualizaciju nastavnog rada kako za darovite, tako i za učenike s prosječnim ili nižim sposobnostima i mogućnostima.

Eksperimentalnim ispitivanjima u oblasti psihologije motivacije dokazano je da je moguće proces školskog učenja učiniti efikasnijim i privlačnijim. Tome doprinosi adekvatno ispitivanje intrinzične (unutrašnje) motivacije u kojoj kognitivne potrebe i radoznalost imaju centralnu ulogu i značaj.

\section{Rad s djecom bez roditeljskog staranja}

Za napuštenu djecu koja su našla utočište i spas $u$ organiziranim ustanovama za prihvat i brigu o njima, posebno je značajno pitanje njihovog integriranja u kolektiv. Uključivanje $u$ zajedničke aktivnosti, prihvatanje i izvršavanje obaveza, osjećaj pripadnosti kolektivu i sigurnost da nisu sami od presudnog je značaja za njihov budući život i rad. 
Kroz integriranje djece u kolektiv ostvaruju se osnovne funkcije integracije kao što su:

- suzbijanje dominacije egocentrizma kao prolazne faze u psihofizičkom razvoju djece;

- prihvatanje normi i pravila ponašanja u kolektivu, sistema vrijednosti i ideala;

- razvijanje, izgrađivanje i njegovanje saradničkih odnosa, kooperativnosti, tolerantnosti i međusobnog razumijevanja;

- razvijanje, izgrađivanje i primjena praktičnih znanja i sposobnosti bitnih za integrativni i saradnički rad.

- cjelovitiju socijalizaciju.

$\mathrm{U}$ integracijskom procesu djece u kolektiv manifestiraju se pozitivne i negativne reakcije. Negativne reakcije je neophodno odmah suzbijati, a pozitivne reakcije sa solidnim obilježjima intenzivno podsticati i razvijati.

Kolektiv predstavlja najpodesniju formu za utvrđivanje razvijenosti sposobnosti prihvatanja $i$ altruizma, tj nivoa prihvatanja i altruizma.

Kooperativnost u kolektivnom radu predstavlja osnovu uspjeha kako kolektiva tako i svakog njegovog člana i s tim u vezi je veoma važno pratiti i utvrđivati opći nivo kooperativnosti.

Sva tri nivoa zajedno omogućavaju intenzivnije, studioznije i sveobuhvatnije praćenje i podsticanje socioemocionalnog razvoja svakog člana kolektiva, svakog učenika u odjeljenju.

Razvijanje sposobnosti saosjećanja, solidarnih reakcija i altruizma ima posebnu vrijednost u odgojno-obrazovnom radu svih nivoa pa i kod prvačića. To neminovno zahtijeva integrativni pristup u kooperativnom, tolerantnom, saradničkom i timskom radu u procesu nastave. Empatija kao značajna komponenta emocionalne inteligencije treba da omogući razvoj distributivne pravde, principa jednakosti, brige i pravde za druge, uključivanje psiholoških procesa, najčešće emocionalnih sa osnovnom svrhom da se razumije drugi i da mu se pomogne. 


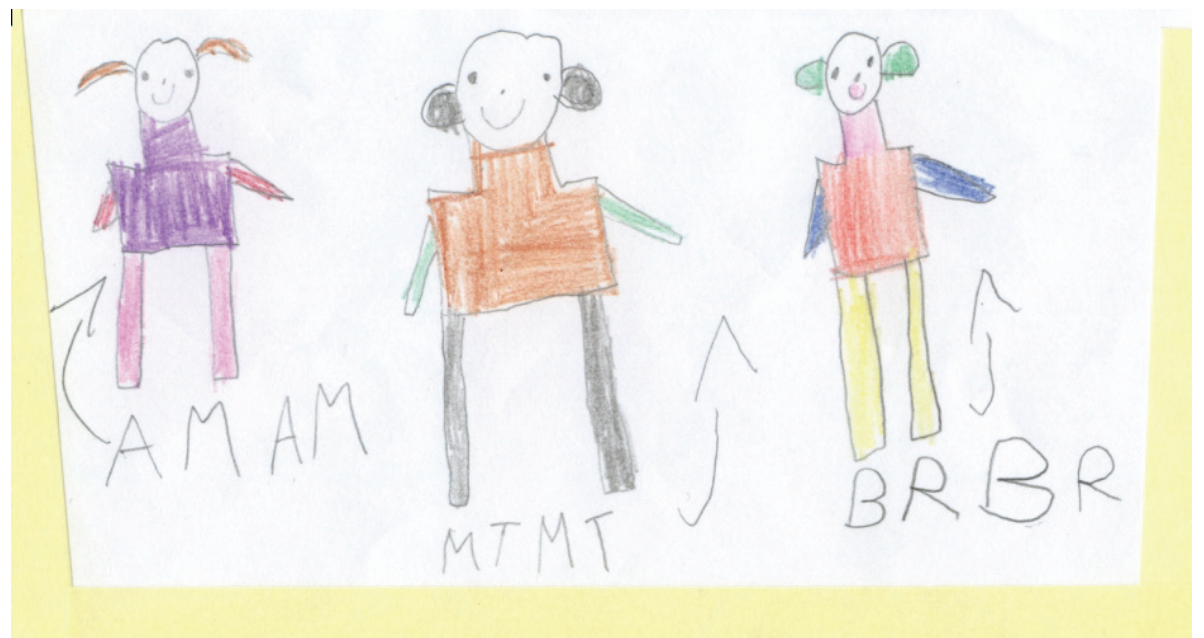

Slika 4

Poremećaji u razvoju govora; dijete iz socijalno - pedagoške zajednice

\section{Zaključci i prijedlog mjera}

U reformisanoj osnovnoj školi učenici prvog razreda zaslužuju posebnu pažnju i tretman, tim prije što se reformom zahtijeva da učenici polaze u školu sa navršenih šest godina;

S tim u vezi, neophodno je kontinuirano raditi na stalnom stručnom usavršavanju kako nastavnika i uopće odgajatelja, tako i roditelja učenika koji sad predstavljaju značajne faktore u odgojno obrazovnom radu škole.

S obzirom da reforma donosi promjene i novine, za uspješnu implementaciju treba stvarati prostorne, materijalno-tehničke i organizacijske uvjete kako bi se zahtjevi mogli ostvariti.

Pozicija učenika, nastavnika i roditelja dobija novu formu koja daje prava i obaveze svim akterima odgoja i obrazovanja. Učenik ima pravo da bude aktivni sudionik nastavnog procesa, ali i obavezu da redovito pohađa nastavu i izvršava postavljene zadatke koji proizilaze iz svakodnevne nastave. Roditeljima je data veća mogućnost da aktivno sudjeluju u praćenju napredovanja i razvoja svoje djece, ali i obaveza da im svakodnevno pomažu u rješavanju njihovih zadataka. Nastavnik se mora permanentno stručno usavršavati kako bi stručno, kvalitetno i kompetentno realizirao zahtjeve nastavnog plana i programa. 
Neminovno se nameće izraženija potreba čvršće saradnje između škola, pedagoških zavoda, ministarstva obrazovanja i nastavničkih fakulteta. Svako sa svoje pozicije treba da doprinese stvaranju preduvjeta za uspješan odgoj i obrazovanje učenika u skladu s reformskim zahtjevima. Stvaranje pretpostavki za materijalno tehničku opremljenost škola kao osnovnog preduvjeta za kvalitetan rad nastavnika i učenika mora biti briga društvene zajednice. Uspješan rad nastavnika u mnogome zavisi od njihove stručne osposobljenosti tokom školovanja. S tim u vezi, novi zahtjevi integrativne škole i nastave zahtijevaju da je nastavnik osposobljen za rad i s djecom koja imaju poteškoće u razvoju, i s djecom s posebnim potrebama kao i s djecom bez roditeljskog staranja. Zato nastavnički fakulteti moraju osigurati, pored ostalog, stručno osposobljavanje budućih odgajatelja iz oblasti specijalne pedagogije i iz oblasti rada s djecom s teškoćama u razvoju.

\section{Literatura}

1. Bošnjak, H. ( 2007) Empatija. Tešanj: Planjax.

2. Ćatić, R., Ramić, O. (1998) Osnovnoškolska pedagogija. Zenica: Pedagoška akademija Zenica.

3. Dizdarević, I. (2002) Agensi socijalizacije ličnosti. Sarajevo: Prosvjetni list.

4. Furlan, I. (1990) Psihologija podučavanja. Zagreb: Školska knjiga.

5. Grgin, T. (1997) Edukacijska psihologija. Jastrebarsko: Naklada Slap.

6. Katel, R.B. (1978) Naučna analiza ličnosti. Beograd: Beogradski izdavačko-grafički zavod.

7. Kvaščev, R. (1975) Podsticanje i sputavanje stvaralačkog ponašanja ličnosti. Sarajevo: IP «Svjetlost».

8. Marinkov, M. (1982) Anksioznost, depresivnost i agresija u psihoterapiji mladih. Psihologija, 1-2: 162-170.

9. Muminović, H. (1998) Mogućnosti efikasnog učenja u nastavi. Sarajevo: Svjetlost.

10. Ramić, O. (1999) Utjecaj karaktera učenika na školski uspjeh i ponašanje. (Magistarski rad), Sarajevo: Filozofski fakultet. 
11. Rathus, S.A. (2000) Temelji psihologije. Jastrebarsko: Naklada Slap.

12. Ross, V., Marshall, M. H., Scott, A. M. (1998). Dječja psihologija. Zagreb: Naklada Slap.

13. Slaviček, M. (1999) Razvoj kreativnosti i osobnosti: Psihološka radionica. Suvremena psihologija, 1 - 2: 155-161.

14. Starc, B., Čudina Obradović, M., Pleša, A., Profaca, B., Letica, M. (2004). Osobine $i$ psihološki uvjeti razvoja djeteta predškolske dobi. Zagreb: Golden marketing-Tehnička knjiga.

15. Stefanović, D. i saradnici (1980). Metodologija rane dijagnostike $i$ rehabilitacije dece ometene $u$ psihofizičkom razvoju (str. 380). Niš: Institut za dokumentaciju zaštite na radu «Edvard Kardelj».

16. Vizek-Vidović, V., Vlahović-Štetić, V., Rijavec, M., Miljković, D. (2003) Psihologija obrazovanja. Zagreb: IEP Vern. 
PROF. DR. OSMAN RAMIĆ, P.H.D.

\section{PECULIARITY OF WORK WITH FIRST GRADE PRIMARY SCHOOL CHILDREN}

SUMMARY

The beginning of the nine year primary school programme has special quality and meaning concerning social and emotional maturity of six year olds and their preparation for fulfilling requirements and doing tasks in the first grade.

The beginning of education is a turning point in child's life and it is very important how the child will cope with it. This turning point is also followed by the reform of education which has the most obvious effect on the first graders. Readiness of children, including children without parental tutorship, for collective work, complicated duties which come from complicated syllabus must become a subject of discussions of psychologists, pedagogues, social workers, teachers and all others that are concerned with education and upbringing of young children. Research of these problems will contribute to solving relevant questions which deal with readiness of six year olds for school and it will also help to teachers who realize the syllabus and educate children to do it successfully. This is especially important for teachers that work with retarded children, children with special needs and children without parental tutorship.

Nowadays these questions are increasingly important; in developed countries that was the case much earlier. Concerning this, the inclusive education has an important role in our system and it is being more and more practised. That is one of the important reasons to continue with the system of professional upgrading and include fields of special pedagogy and psychology for the handicapped children. 
الأستاذ الدكتور عثمان راميتش

\section{خصوصيات العمل مع تلاميذ الصف الأول الابتائي}

\section{الملخص}

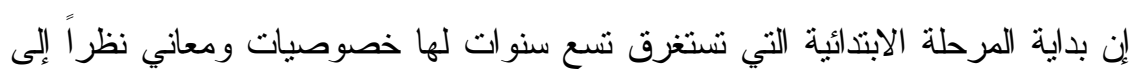

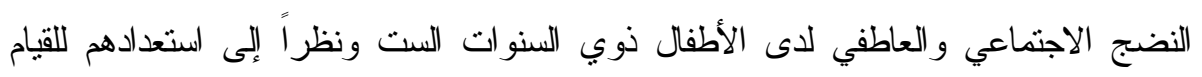

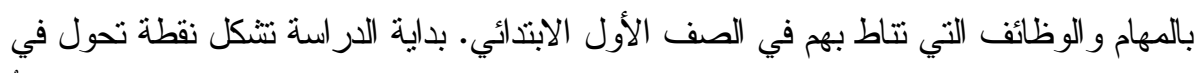

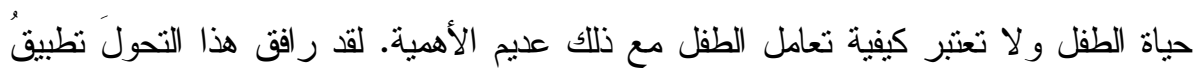

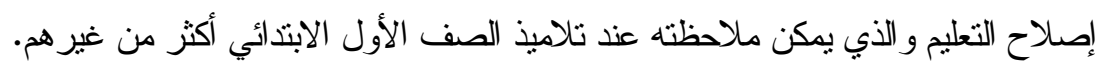

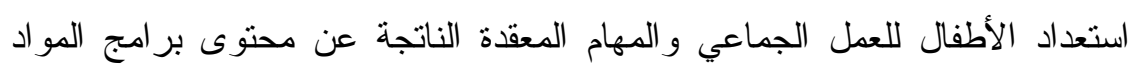

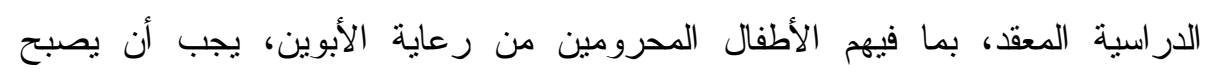

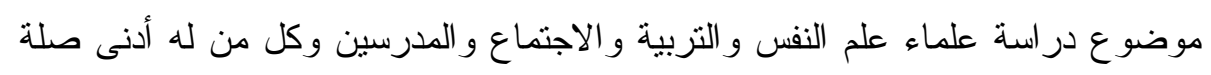
بمسألة تربية وتعليم الأطفال الناثشئين.

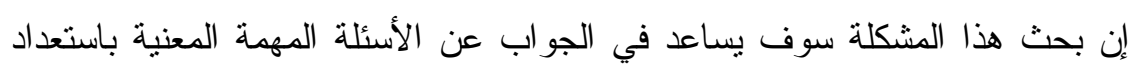

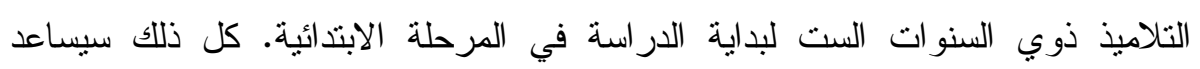

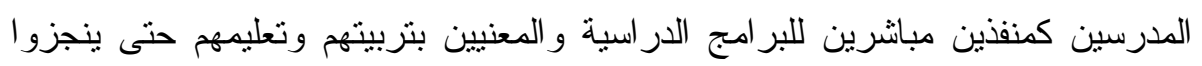

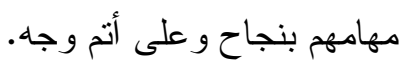
كل هذا له أهمية خاصة لنجاح مهمة المدرسين المسؤولين عن الأطفال الذين يعانون

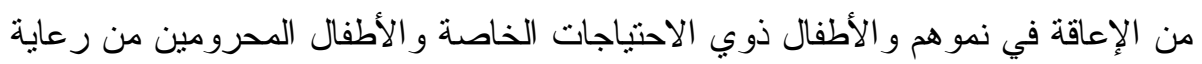

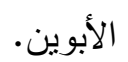

أصبحت هذه الدسائل لها أهية بالغة في العصر الراهن، ولكن الدول الدتحضرة

$$
\text { أدركت أهيتها منذ وقت طويل. }
$$

و عليه فإن التربية والتعليم الثامل للجميع لهما دور مهم وأصبح ينمو في نظامنا التربوي و التعليمي. ذلك سبب من الأسباب المهمة لإعطاء العناية الكافية في نظام تأهيل

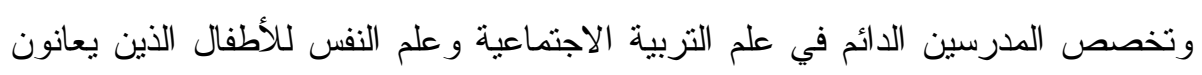
من الإعاقة في نمو هم. 